\author{
目崎 久美*1, 花岡 俊仁 ${ }^{* 1}$, 福原 哲治*1 \\ 小林 一泰*1, 白川 敦子*2
}

\begin{abstract}
要 旨
症例は 62 歳男性． 右上葉の肺膿瘍による血痰が持続し手術目的に紹介となった．高度の漏斗胸を伴っていた．左側臥位， 片肺換気下に後側方切開で開胸し右上葉切除術を行った．全体的に炎症が強く，易出血性で多量の出血を伴った．肺尖部で は空洞部が胸郭にくい込むように広がっていた，組織培養で Aspergillus flavus が検出された．

術後, 抗真菌剂も併用して加療し，全身状態は安定していた。しかし，術後 39 日目から発熱と咳が出現し，術後 40 日目 にかけて急激に呼吸不全となり，NPPV を開始した．画像検査では心拡大と健側である左側にのみすりガラス影が出現した. うっ血の関与を疑い, 感染コントロールとともに利尿薬，カルペリチドを開始し，数日の経過で呼吸状態，左肺野の陰影は ともに改善した。

右肺優位の高度の漏斗胸と右上葉切除により相対的に左肺の血流が増加し，左側の片側性の肺水腫を生じた可能性が考え られた。
\end{abstract}

索引用語：漏斗胸, 肺切除, 健側, 片側性肺水腫

Pectus excavatum, pulmonary resection, contralateral lung, unilateral pulmonary edema

\section{はじめに}

肺切除術後の呼吸不全の原因としては, 間質性肺炎, 心不全, ARDS などが挙げられるが, いずれも両側性に 生じることが多く, 片側性は稀である. 今回, 漏斗胸を 伴い, 肺膿瘍の術後に健側の片側性肺水腫を生じ, 呼吸 不全に陥った 1 例を経験したので報告する.

\section{症例}

症 例: 62 歳 男性.

主 訴: 血痰.

現病歴：糖尿病で当院内科通院中であった．以前より 時々血痰があり, 右肺尖に炎症性変化を指摘されていた。

\footnotetext{
*1住友別子病院外科

*2同病理診断科

原稿受付 2013年11月20日

原稿採択 2014年 1 月 5 日

本論文の要旨は第 30 回日本呼吸器外科学会総会にて発表し た.
}

3 カ月前から血痰の量が増加し, 止血剤で加療したが持 続したため, 手術目的に当科紹介となった。

既往歴：漏斗胸, 25 歳から 1 型糖尿病, 58 歳時に肺炎 にて 2 力月間入院加療.

喫煙歴 : 51 歳まで 20 本 $/$ 日 $\times 31$ 年間.

入院時現症：身長 $170.5 \mathrm{~cm}$ 体重 $52.6 \mathrm{~kg}$ 体温 36.0 度 血圧 $134 / 70 \mathrm{mmHg}$ 脈拍 $58 \mathrm{bpm}$ 糖尿病はイン スリンを使用しコントロール良好であった。

血液検査所見：WBC $6100 / \mu \mathrm{l}, \mathrm{CRP} 0.1 \mathrm{mg} / \mathrm{dl}$ と炎症 所見は認めなかった. HbAlc は $6.3 \%$ と軽度高值であっ た．その他に特記すべき異常を認めず．血液ガス分析 pH 7.423 PaO2 83.9 mmHg PaCO2 43.5 mmHg HCO3$27.0 \mathrm{mmol} / 1$.

胸部 X 線 (Fig. 1)：正中やや右側を中心とした高度の 漏斗胸と右上肺野に浸潤影を認めた。

胸部 CT (Fig. 2)：肺尖部の胸膜肥厚, 右上葉の体積縮 小と貯留物を伴う空洞化, 気管支拡張を伴う部分を認め た。

呼吸機能検査所見：\%VC $67.1 \%, \mathrm{FEV} 1.0 \% 79.6 \%$ 


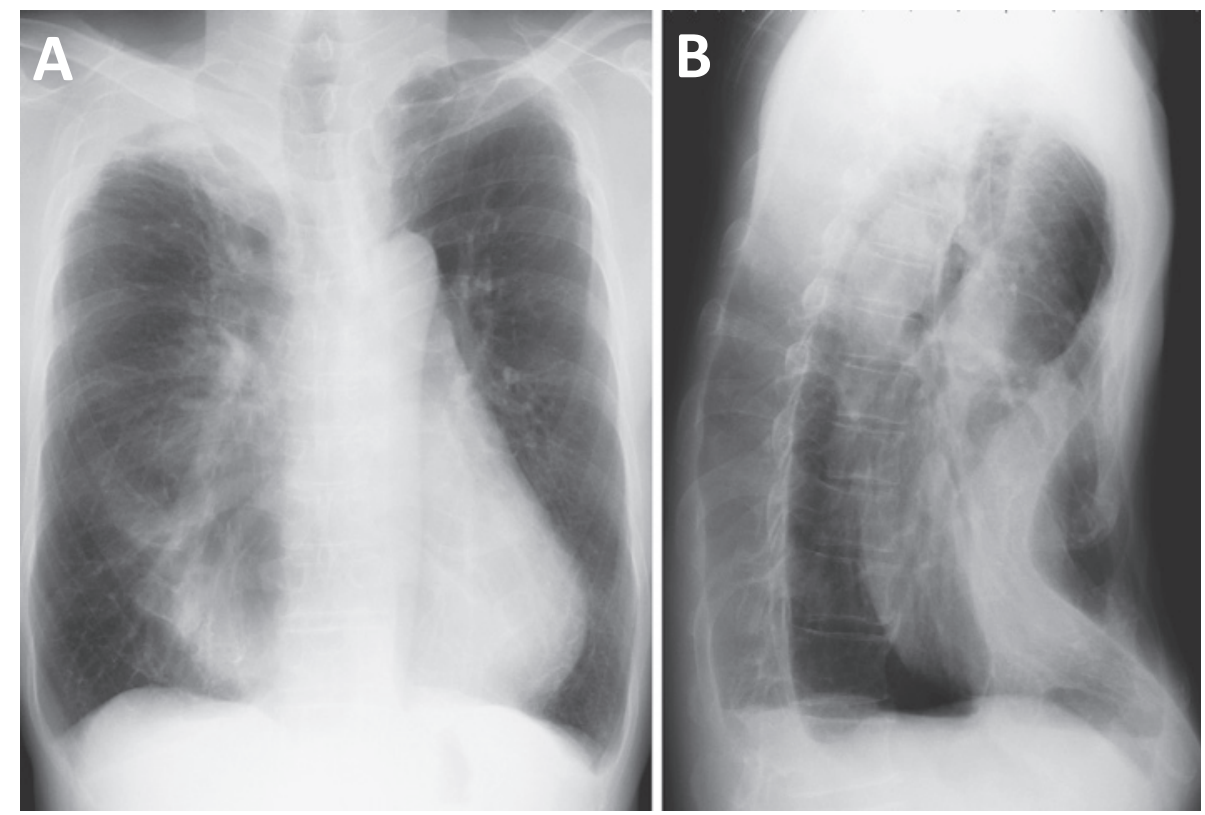

Fig. 1 A chest radiograph with a dorsoventral view showed an infiltrative shadow in the right upper lung field (A), and a lateral view showed severe pectus excavatum (B).
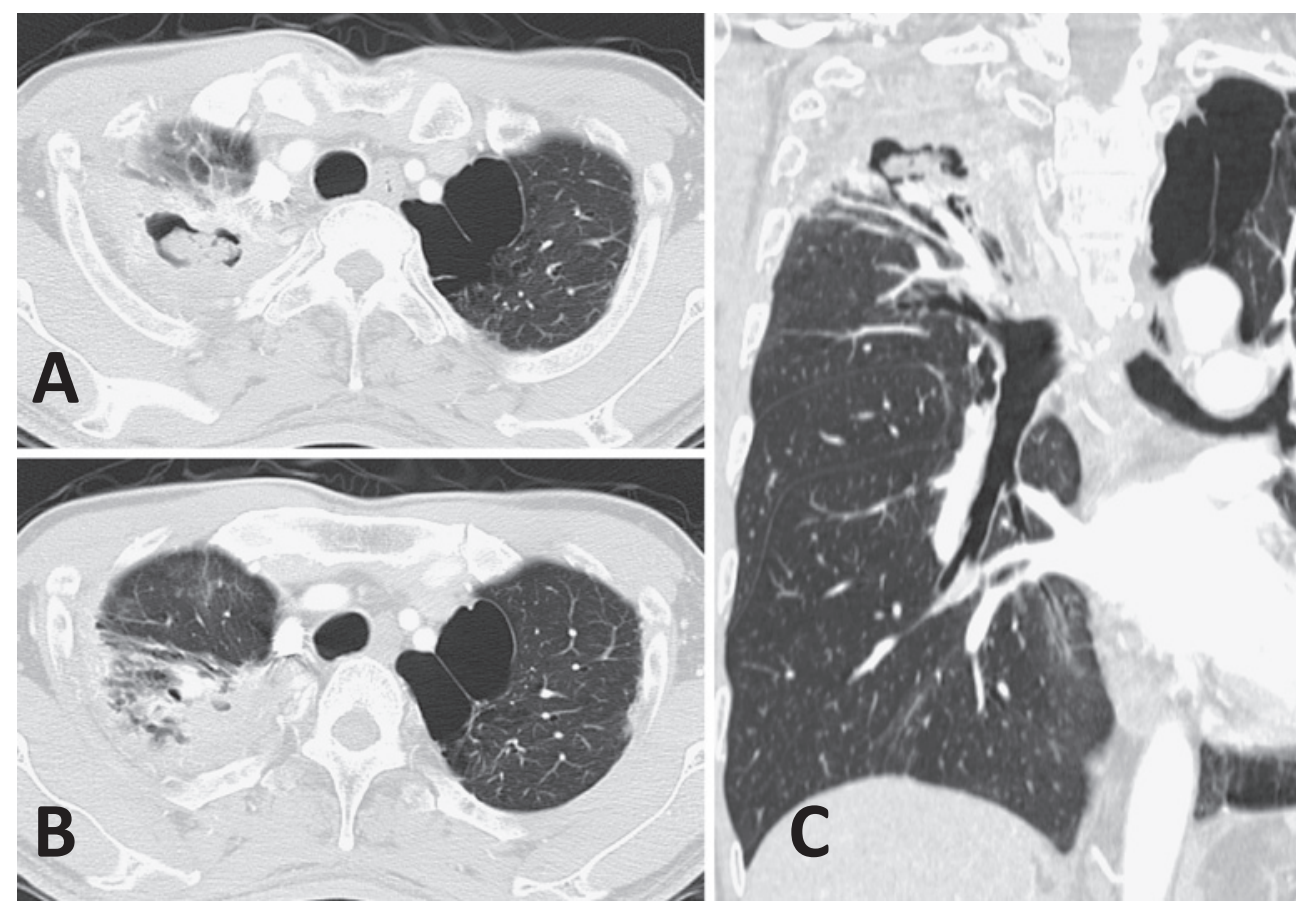

Fig. 2 Chest CT showed an infiltrative shadow with a cavity at the apex of the right lung (A, $\mathrm{B}, \mathrm{C}$ ).

と中等度の拘束性障害を認めた。

心エコー所見：EF $74 \%$ と良好で軽度 PR を認めるの みであった。
喀痰培養：抗酸菌 $(-)$, その他にも有意な菌は検出さ れず.

以上より, 荒廃した右上葉から少量の出血が持続して 

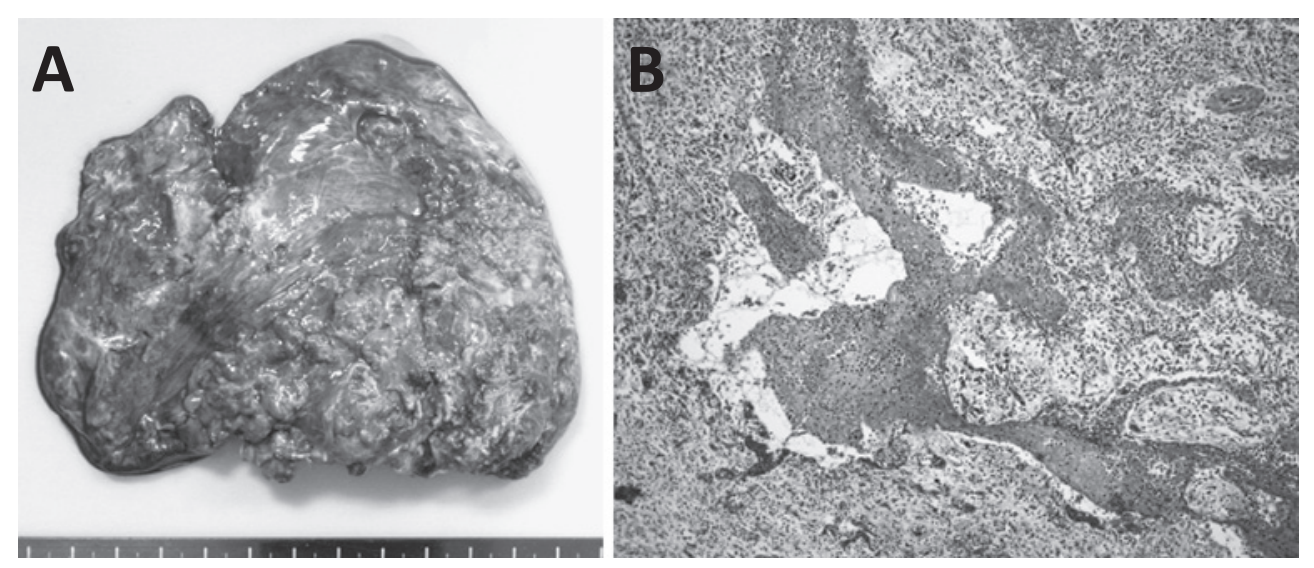

Fig. 3 The resected right upper lobe was hard with inflammation (A). Histological findings showed chronic inflammation characterized by enlargement of the bronchus, destruction of alveoli, formation of follicles with lymphocytes, and fibrosis (B).

いると考えられた. 内科的治療では止血が得られないた め, 手術の方針となった.

手術所見 : 左側臥位, 片肺換気下に右第 5 肋間にて後 側方切開で開胸し, 右上葉切除術を行った. 右上葉は全 体に胸壁と強固に癒着しており, 剥離すると易出血性で コントロール困難であった. 出血を減らすため, 先に血 管処理を行い, 輸血を準備した後に, 特に炎症が強い肺 尖部の剥離を行った，右上葉空洞部は胸郭にくい込むよ うに広がり, 赤褐色の液貯留を少量認めた. 最後に上葉 気管支を切離して切除を完了し，止血の後に手術を終了 した. 手術時間 5 時間 13 分, 出血は $5620 \mathrm{ml}$ と多量とな り, 術中 MAP12 単位, FFP6 単位, 血小板 20 単位を要 した。

病理組織所見 (Fig. 3) : 気管支拡大, 肺胞壁の破壊, 線維性結合組織による肺胞の置換, 骨化, 間質のリンパ 滤胞形成など慢性炎症像を認めた. 組織の細菌学的検査 では, 塗抹で細菌, 真菌ともに陰性であったが, のちに 培養でAspergillus flavus が（1+）検出された，抗酸菌 は陰性であった。

術後経過：抗生剤は術中術後にFMOXを使用してい たが，微熱が持続したため術後 3 日目よりMEPM0.5 g/ 回 $\times 2$ 回に変更した. 術後のドレーン排液の培養検査で も Aspergillus flavus が少数検出され, 抗真菌剤 $(\mathrm{MCFG})$ を術後 8 日目から追加した. 術後 9 日目の血液検査では, アスペルギルス抗原, 抗体はともに陰性で, $\beta$-D グルカン は $29 \mathrm{pg} / \mathrm{ml}$ （基準值 $20 \mathrm{pg} / \mathrm{ml}$ 以下）であった. 術後 21 日目よりSTFX と ITCZ の経口薬に変更し，継続した。
呼吸状態は安定していたが, 37 度前後の微熱と炎症反応 の軽度高值 (WBC6000-7000/ $\mathrm{mm}^{3}, \mathrm{CRP} 2-3 \mathrm{mg} / \mathrm{dl}$ ) が持 続し, $\beta-\mathrm{D}$ グルカンは $20-30 \mathrm{pg} / \mathrm{ml}$ と軽度高值で推移し た. CTでは右肺尖部に被包化された液体譻留を認め, 経 過を追って必要があればドレナージを検討する方針と なった. 食事摂取, 水分出納などは大きな問題なく経過 していた.

術後 39 日目に 37.8 度の発熱, 咳が出現し, 術後 40 日目には 38.1 度の発熱となり, 呼吸苦, 低酸素血症が急 速に悪化し起坐呼吸となった。吸入酸素濃度を上げるも $\mathrm{PaO} 2 / \mathrm{FiO} 2$ は $150 \mathrm{mmHg}$ 程まで低下し, ICUに入室の 上, 非侵襲的陽圧換気療法 (NPPV) 開始し, エラスター ゼ阻害薬を追加した，血液検査では，WBC10160/ $\mathrm{mm}^{3}$, $\mathrm{CRP} 9.9 \mathrm{mg} / \mathrm{dl}$ と炎症反応の上昇を認めた。胸部 X 線, CT では左肺野にのみすりガラス影が出現し（Fig. 4A, B), 漏斗胸のために左側にせり出すような心拡大を認め た.うっ血の関与を考え, 利尿薬, カルペリチドを開始 した. 感染症に対しては抗生剤を MEPM1 g/回×3 回+ CPFXに, 抗真菌剤を MCFGに変更し, 免疫グロブリン 製剤も併用しコントロールを行った. 術後 41 日目の血液 検查では, アスペルギルス抗原は陰性, $\beta-D$ グルカンは $32.4 \mathrm{pg} / \mathrm{ml}$ であった.これらの治療に速やかに反応し, 酸 素化, 胸部陰影, 炎症反応ともに数日の経過で改善した (Fig. 4C，D)。術後 44 日目にNPPV を離脱し，術後 45 日目にICUを退室した。 その後も感染症の加療を継続 し, 全身状態, 炎症反応の改善を認め, 肺尖部の液体貯 留も縮小傾向となった. 術後 49 日目で抗生剂は終了し, 


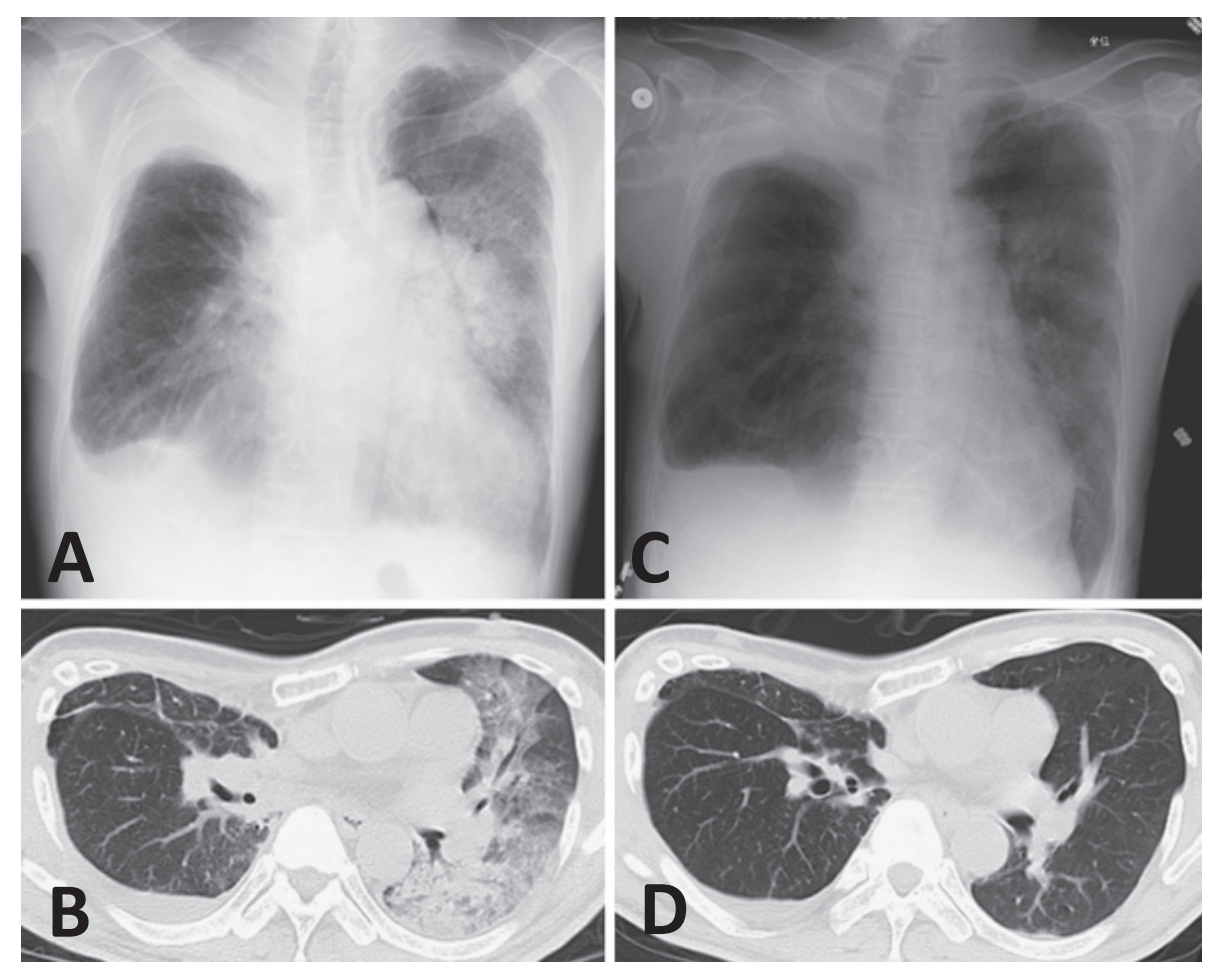

Fig. 4 On the $40^{\text {th }}$ postoperative day, auxocardia and a ground glass pattern in the left lung field appeared on radiograph (A) and CT (B). With treatment, the lung field became clearer the next day $(\mathbf{C})$, and the shadow disappeared on CT on the $49^{\text {th }}$ postoperative day (D).

抗真菌剤は 72 日目より ITCZ に切り替えた。術後 81 日 目に退院となり, ITCZ は退院後 3 力月間内服継続し, 経 過良好のため中止した. 術後 2 年以上経過するが, 真菌 症の再燃を認めていない.

\section{考察}

術後の呼吸不全における肺野の陰影は, 多くは両側性 に生じ，片側性は稀である，検索しえた限りでは本邦に おける術後の片側性の肺障害で呼吸不全を呈した報告は 6 例のみであった ${ }^{1.5)}$. 肺切除後の再膨張性肺水腫と考え られた 1 例 $^{11}$ は手術と同側に発症していた. しかし, その 他の肺切除術後の 3 例 24$)$ では, 手術と反対側の健側にの みすりガラス影が出現し, ARDS や肺線維症となり死亡 している. いずれの症例でも, 健側肺にのみ肺障害を生 じた原因は明らかではないが，片肺換気による健側肺へ のストレスによる影響が推察されていた，自験例におい ても, 術中の片肺換気による肺実質の障害が原因となっ た可能性は否定できないが, 術後 39 日目という急性期を 過ぎた時期に生じたこと, 心拡大を認め利尿薬に速やか
に反応したことなどを考えあわせると, 肺水腫が片側性 に生じた可能性が高いと考えられた。

肺水腫は, 肺血管静水圧の上昇による心原性と, 肺血 管透過性の立進による非心原性に大別される，肺血管静 水圧の上昇は心疾患, 循環血液量の増加などにより生じ, 肺血管透過性の立進は ARDSに代表され, 感染, アレル ギーなどにより生じる. 自験例における肺水腫の原因を 考えると, 術後経過と発熱, 炎症反応上昇からは, アス ペルギルス感染症の増悪により, 血管透過性が元進した ことが契機になったと考えられる.ささらに，心拡大を伴 い, 利尿薬に速やかに反応したことからは, うっ血性心 不全の要素も加わっていたと考えられた.

片側性の肺水腫は稀な病態であり, 心不全によるもの は右側に生じることが多いとされる。その原因は明らか ではないが, 重力や姿勢, 肺静脈圧の変化, 毛細血管の 浸透圧の変化などが考えられている 開心術直後の心不全により, 右側の片側性肺水腫を生じ 呼吸不全に陥った症例であった。自験例では, 術前から の心疾患を認めず, 左側に生じ, 心エコーで明らかな心 
機能の低下を認めなかった，そのため, 心不全の報告と は原因が異なると考えられる.

自験例において健側の片側性肺水腫が生じた原因を考 察すると, 非手術側に生じているため, リンパ還流や交 感神経への手術による影響は否定的である．また，肺血 管透過性の充進や肺の気腫性変化による影響が片側に優 位に生じることは考えにくい，そのため，何らかの原因 で肺血管静水圧の上昇が片側優位に生じたと推察され る. 術前, 術後の胸部 CT を再度検討したが, 漏斗胸や肺 切除に起因する肺動静脈, 心臓の圧排, 屈曲など肺血管 静水圧の左右差への関与が疑われる所見は認められな かった. 一方, 肺循環血液量について考えると, 右側優 位の高度の漏斗胸により右胸腔が狭いことが影響した可 能性があげられる。また, 肺癌の手術, 放射線療法の 5 年以上の後に対側に生じた片側性肺水腫の報告 ${ }^{6}$ もあり， 肺切除による血管床の減少が対側の肺水腫の発生に関与 している可能性も考えられる. つまり, もともと漏斗胸 により右の胸腔が狭く, 相対的に左側に血流分布が大き かった，そこに，右上葉切除による血管床減少が加わり， さらに左肺の血流量が増加していた．その状況下に感染 を契機に血管透過性の㠵進が生じ, うっ血性心不全も加 わり, 左肺のみの肺水腫に至ったものと推察される。し かし, 文献的に漏斗胸や肺切除と肺水腫の関係に関する 報告はないため, 推察の域を越えず, 今後の報告が待た れる。

\section{結語}

肺膿瘍の術後に, 健側の片側性肺水腫を生じた稀な 1
例を経験した． 右側優位の高度の漏斗胸と右上葉切除に よる左側への相対的な血流量増加が関与している可能性 があるが，はっきりした原因は不明である。類似の報告 例はほとんどなく，示唆に富む 1 例と考えられたため報 告した.

\section{利 益相反}

本論文について申告する利益相反はない.

\section{文献}

1. 西木戸修, 田尻 治, 舘田武志, 田中麻香, 大橋弥生, 山 中郁男. 胸腔鏡下右上葉切除術後に発生した片側性肺水 腫の 1 例. 日臨麻会誌 2003; 23: 261-3.

2. 渡 正伸, 片山達也. 肺癌術後に健側肺に間質性肺炎像が 出現し ARDS となった 1 症例. 日呼外会誌 2006; 20: 62630.

3. 木村 哲, 水谷太郎. 片肺換気麻醉後に健側肺のみに生じ た肺線維症の 1 症例. 麻酔 2001; 50: 651-4.

4. 上吉原光宏, 伊部崇史, 永島宗晃, 竹吉 泉, 滝瀬 淳, 堀江健夫, 他. 肺悪性腫瘍術後, 急速な発症を来した急性 呼吸促迫症候群の 1 例. 日胸臨 2010; 69: 453-8.

5. 中村裕昌, 山口裕己, 中尾達也, 大島 祐, 徳永宜之, 光 山晋一, 他. 開心術後発症した片側性肺水腫に対して, VV ECMO を使用し救命しえた 2 例. 日心臟血管外会誌 2011; 40: 172-6.

6. 伊藤博道, 山本達生, 齋田幸久, 石川成美, 鬼塚正孝, 野 口雅之. 肺腺癌治療後に認められた一側肺浮腫の 1 例. 肺 癌 2005; 45: 31-6. 


\title{
A case of unilateral pulmonary edema with pectus excavatum after surgery for lung abscess
}

\author{
Kumi Mesaki*1, Toshihito Hanaoka*1, Tetsuji Fukuhara ${ }^{* 1}$ \\ Kazuyasu Kobayashi ${ }^{* 1}$, Atsuko Shirakawa*2 \\ ${ }^{* 1}$ Department of Surgery, ${ }^{* 2}$ Department of Pathology, Sumitomo-Besshi Hospital
}

A 62-year-old man, who showed severe pectus excavatum, complained of frequent hemoptysis. CT revealed a small cavity with abscess at the apex of the right lung. Hemoptysis, considered to originate from the destroyed lung, persisted inspite of medical treatment. Then, right upper lobectomy was performed, and Aspergillus flavus was isolated from the lung tissue. After the operation the patient was treated with antibiotics and an antifungal agent and his general condition was mostly favorable. On the $39^{\text {th }}$ day after the operation, the patient experienced a high fever and cough and, on the next day, rapidly developed dyspnea and hypoxemia. Radiograph and CT demonstrated auxocardia and the groundglass pattern only in the left lung field. We started NPPV and treated him with a diuretic and carperitide in addition to infection control. Then, hypoxemia and the lung shadow disappeared in a few days. He was treated with an antifungal agent and discharged on the $81^{\text {st }}$ day after the operation. The treatment for aspergillosis was continued for several months.

It is possible that unilateral pulmonary edema occurred because of the relatively larger pulmonary blood flow of the left lung which arose due to severe pectus excavatum and resection of the right upper lobe.

(C) The Japanese Association for Chest Surgery (JACS) 